\title{
MARGINAL FIT AT CYLINDER-ABUTMENT INTERFACE BEFORE AND AFTER OVERCASTING PROCEDURE
}

\author{
ADAPTAÇÃO MARGINAL NA INTERFACE INTERMEDIÁRIO-CILINDRO \\ ANTES E APÓS AS SOBREFUNDIÇÕES
}

\author{
Luciana Martins Cres MORAES ${ }^{1}$, Paulo Henrique Orlato ROSSETTI ${ }^{1}$, Leylha Maria Nunes ROSSETTI ${ }^{1}$, \\ Ana Paula Ribeiro do Vale PEDREIRA ${ }^{2}$, Accacio Lins do VALLE ${ }^{3}$, Wellington Cardoso BONACHELA ${ }^{3}$
}

\author{
1- DDS, MSc, Graduate Student, Department of Prosthodontics, Bauru School of Dentistry, University of São Paulo, Brazil. \\ 2- DDS, Graduate Student, Department of Prosthodontics, Bauru Dental School, University of São Paulo, Brazil. \\ 3- DDS, MSc, PhD, Associate Professor, Department of Prosthodontics, Bauru Dental School, São Paulo University, Brazil. \\ Corresponding address: Dr. Wellington Cardoso Bonachela - Faculdade de Odontologia de Bauru - Alameda Octávio Pinheiro Brisolla, 9-75 \\ 17012-901 Bauru, SP, Brazil - E-mail:wbonach@fob.usp.br \\ Received: March 07, 2005 - Modification: May 10, 2005 - Accepted: June 27, 2005
}

\begin{abstract}
7

Lhe aim of this study was to measure marginal fit at cylinder-abutment interface, before and after overcasting procedure. A hexagonal implant was fixed to a stainless steel base and a Estheticone-like abutment used during all the experiment. Before casting procedure, gold (Group I) and Ni-Cr-Be (Group II) premachined cylinders were tightened to the abutment with gold and titanium screws (in both groups), with $10 \mathrm{Ncm}$ and $20 \mathrm{Ncm}$ torque values for the same screw type. Vertical measures were taken at the light microscope (Mitutoyo 5050, Tokyo, Japan) three times in six different parts along the abutment-cylinder interface for each torque value. Cylinders were overcast with AgPd (Group I) or Ni-Cr-Be (Group II) alloy. After casting, the same measures and torque values were repeated. Intragroup differences (10 or $20 \mathrm{Ncm}$ torque values, before and after casting) and intergroup differences (10 and 20Ncm torque values, before or after casting) were analyzed by the Paired $t$ Test; $(\mathrm{p}<0.05)$. Intragroup differences were observed for G-I (gold, 20Ncm, titanium screw, $\mathrm{p}=0.044)$ and for GII (Ni-Cr-Be, 10Ncm, gold screw, p=0.002). Intergroup differences only were not observed in the G-II group (Ni-Cr-Be, 10 and $20 \mathrm{Ncm}$, titanium screw, $\mathrm{p}=0.534$ ). Within the limits of this study, the following conclusions can be drawn: 1) Regardless of screw type, marginal misfit was higher for Ni-Cr-Be cylinders after casting, but within acceptable levels of fit; 2) The combination of gold cylinders with gold or titanium screws was the most effective to reduce marginal misfit; 3) Both screw types did not improve marginal fit of Ni-Cr-Be cylinders after overcastting, and 4) Although a 20Ncm torque improved marginal fit in all situations, its use is not recommended due to the increased risk of prosthesis failure. Ni-Cr-Be alloys may be successfully used in single-tooth implant restorations, with no damage to the fit between abutment and prosthetic cylinder.

Uniterms: Marginal fit; Prosthetic cylinder; Dental alloys; Casting; Dental implants.
\end{abstract}

\begin{abstract}
RESUMO
objetivo deste estudo foi medir a adaptação marginal na interface intermediário-cilindro, antes e após a sobrefundição. Um implante do tipo hexágono externo afixado numa base de aço inoxidável e um intermediário do tipo Estheticone foram usados durante todo o experimento. Antes das fundições, cilindros pré-usinados de ouro (Grupo I) e de Ni-Cr-Be (Grupo II) foram aparafusados ao intermediário com parafusos de ouro e titânio em ambos os grupos, com torques de $10 \mathrm{Ncm}$ e $20 \mathrm{Ncm}$ para o mesmo tipo de parafuso. As medidas verticais foram feitas num microscópio óptico (Mitutoyo 5050, Tóquio, Japão) três vezes em seis locais diferentes ao longo da interface intermediário-cilindro para cada valor de torque. Os cilindros foram encerados e fundidos tanto em liga de Ag-Pd (Grupo I) ou liga de Ni-Cr-Be (Grupo II). Após as fundições, as mesmas medidas e os mesmos valores de torque foram repetidos. As diferenças intra-grupo (torques de $10 \mathrm{ou} 20 \mathrm{Ncm}$, antes e após as fundições) e as diferenças inter-grupos (torques de 10 e $20 \mathrm{Ncm}$, antes ou após as fundições) foram analisadas pelo teste t pareado $(p<0.05)$. Diferenças intra-grupo foram observadas em G-I (ouro, 20Ncm, parafuso de titânio, p=0,044) e em G-II (Ni-Cr-Be, 10Ncm, parafuso de ouro, $\mathrm{p}=0,002)$. As diferenças inter-grupos não foram observadas somente no grupo G-II (Ni-Cr-Be, 10 e $20 \mathrm{Ncm}$, parafuso de titânio, p=0,534). Dentro dos limites deste estudo, as seguintes conclusões podem ser feitas: 1) Independente do tipo de parafuso, os valores de desadaptação marginal foram mais altos para os cilindros de Ni-Cr-Be após as fundições, mas dentro dos níveis aceitáveis de adaptação; 2) A combinação cilindro de ouro com parafuso de ouro ou de titânio foi a mais efetiva para reduzir o desajuste marginal; 3) Ambos os tipos de parafusos não melhoraram a adaptação marginal dos cilindros de Ni-Cr-Be após as fundições, e 4) Embora um torque de $20 \mathrm{Ncm}$ tenha melhorado a adaptação marginal em todas as situações, seu uso não é recomendado devido ao risco aumentado de falha na prótese . As ligas de Ni-Cr-Be podem ser usadas com sucesso nas restaurações unitárias sobre implantes, sem prejuízo na adaptação entre o abutment e o cilindro protético.

Unitermos: Adaptação marginal; Cilindro protético; Ligas metálicas; Fundição; Implantes dentários.
\end{abstract}




\section{INTRODUCTION}

Screwed tooth implant restorations have had their clinical success reported in the literature ${ }^{1-10}$. However, when the interfaces of a screw joint are not accurately aligned due to misfit, the joint assembly process is seriously compromised. As a result, any external loads (chewing) applied to the prosthesis are directed to the screw instead of being dissipated into the implant stack, resulting in screw back out and fatigue fracture ${ }^{11}$. Clinically, screw damage is preferred rather than a new metalloceramic crown ${ }^{12}$.

In some instances, a prosthetic cylinder is incorporated to the final prosthesis, increasing operational costs. To overcome this problem, dental restorations directly waxedup and cast onto plastic burnout abutments became widespread. ${ }^{13}$ Even thus, premachined cylinders have more precision than castable ones. More recently, CAD/CAM technology developed zirconia abutments ${ }^{14,15}$ for excellent fit and esthetics, but at higher cost levels. Therefore, even premachined cylinder-abutment interface shows marginal gaps from 0 to $119 \mathrm{~mm}^{16-18}$.

Thereby, better margins at the cylinder-abutment interface with suitable cost-benefit ratios are necessary. Based on the long-term success of base metal alloys ${ }^{19}$ for fixed partial dentures, the use of Ni-Cr-Be premachined cylinders could reduce operational costs and still maintain acceptable fit levels. From a technical standpoint, overcasting would be easy due to the same oxide formation between alloy and premachined cylinder. However, two questions may arise: first, which combinations among cylinder and screws would play some role into the marginal fit; second, the influence of overcasting to these new cylinders.

The aim of this study was to measure the marginal fit at Ni-Cr-Be and gold cylinder-abutment interfaces before and after overcastting procedure with Ni-Cr-Be and Ag-Pd alloys, alternating gold and titanium screws. The null hypotheses tested were: 1 ) there are no intragroup differences (10 or $20 \mathrm{Ncm}$ torque values, before and after casting) and 2) there are no intergroup differences ( 10 and $20 \mathrm{Ncm}$ torque values, before or after casting).

\section{MATERIALAND METHODS}

A hexagonal implant with $15 \mathrm{~mm}$ length $\mathrm{x} 3.75$ diameter (Conexão Sistemas de Prótese São Paulo, SP) was fixed to a stainless steel hexagonal base especially designed for this study. An EsthetiCone-like abutment (Conexão Sistemas de Prótese, Ltda.) was mounted with $20 \mathrm{Ncm}$ torque value. Two types of prefabricated prosthetic cylinders were combined with this abutment: gold (Group I, Conexão Sistemas de Prótese Ltda) and an experimental Ni-Cr-Be (Group II, C.O.B.E., Brazil) premachined cylinder. Before use, cylinders in both groups were inspected under $10 \mathrm{X}$ magnification (Mitutoyo 5050, Tokyo, Japan) for marginal imperfections or debris. Unsatisfactory specimens (1\%) were discarded. Cylinder, screw types, and torque values are listed in Table 1. (Figure 1)

The experimental study design consisted of two phases: before and after casting procedures. Before casting, gold and titanium screws in both groups were initially screwed to the abutment with $10 \mathrm{Ncm}$ and $20 \mathrm{Ncm}$ torque values (Torque Controller, Nobel Biocare, Gotemburg, Sweden). The adopted values simulated an attempt to improve marginal $\mathrm{fit}^{22}$. Samples were positioned in a light microscope (Mitutoyo 5050, Tokyo, Japan) and vertical measurements

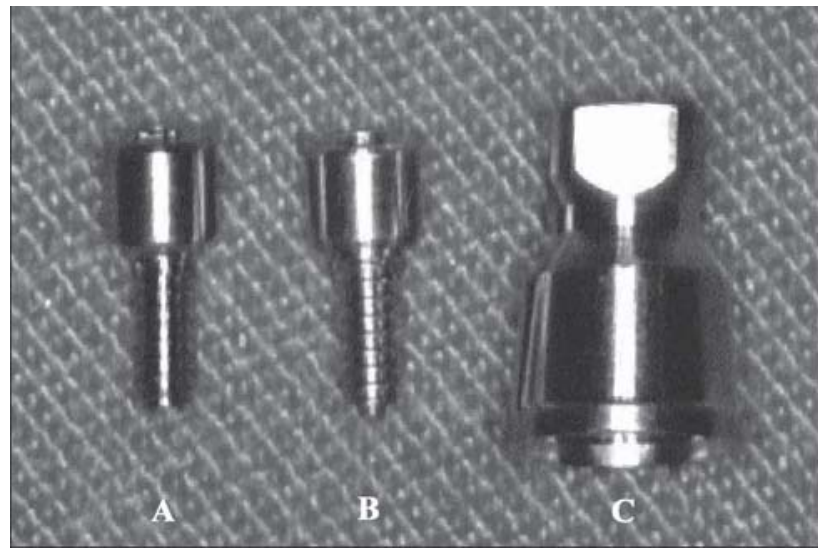

FIGURE 1- Titanium screw, gold screw, premachined abutment (left to right)

TABLE 1- Cylinder, screw and torque values used in this study

\begin{tabular}{|c|c|c|c|c|}
\hline Group & Screw type & Torque value & Manufacturer & Code \\
\hline & Gold (n=8) & $10 \mathrm{Ncm}$ & Conexão & 106002 \\
\hline \multirow[t]{4}{*}{ Gl (gold) n=8) } & & $20 \mathrm{Ncm}$ & & \\
\hline & $\mathrm{Ti}(\mathrm{n}=8)$ & $10 \mathrm{Ncm}$ & Conexão & 106002 \\
\hline & & $20 \mathrm{Ncm}$ & & \\
\hline & Gold (n=8) & $10 \mathrm{Ncm}$ & C.O.B.E. & - \\
\hline GII (Ni-Cr-Be) & & $20 \mathrm{Ncm}$ & & \\
\hline \multirow[t]{2}{*}{$(n=8)$} & $\mathrm{Ti}(\mathrm{n}=8)$ & $10 \mathrm{Ncm}$ & C.O.B.E. & - \\
\hline & & $20 \mathrm{Ncm}$ & & \\
\hline
\end{tabular}


were taken three times at six different parts along the abutment-cylinder interface for each torque value (Figure 2).

After that, single unit frameworks in both groups were obtained as follows: an initial wax-up with a premolar contour was done directly to the screwed abutment (Figure 3). A silicone mold (Optosil, Kuzler) was formed to standardize all wax patterns. Thus, melted wax was poured into the silicone mold to obtain 16 similar wax patterns. Then, samples were invested and overcast either with a Ag-Pd (Proton, Lacroix Ltda., Rio de Janeiro, Brasil) or Ni-Cr-Be (Vera Bond II, Albadent, Califórnia, USA) alloy according to manufacturer's instructions. Samples were divested and internally cleaned with $45 \%$ hydrofluoric acid. To protect external margins from scratching after cleaning, abutment analogues were screwed and restorations blasted with glass bead particles.

After casting, samples were tightened in the same way and vertical measurements taken as previously described. Additional scanning electron microscope analysis was performed to evaluate marginal fit qualitatively in both groups (Figures 4a, 4b).

Statistical analysis was conducted with the aid of a software (Sigma Stat 2.0, Jandel Corporation, California, USA). Intragroup differences before and after casting (10 or $20 \mathrm{Ncm}$ torque values) and intergroup differences before or

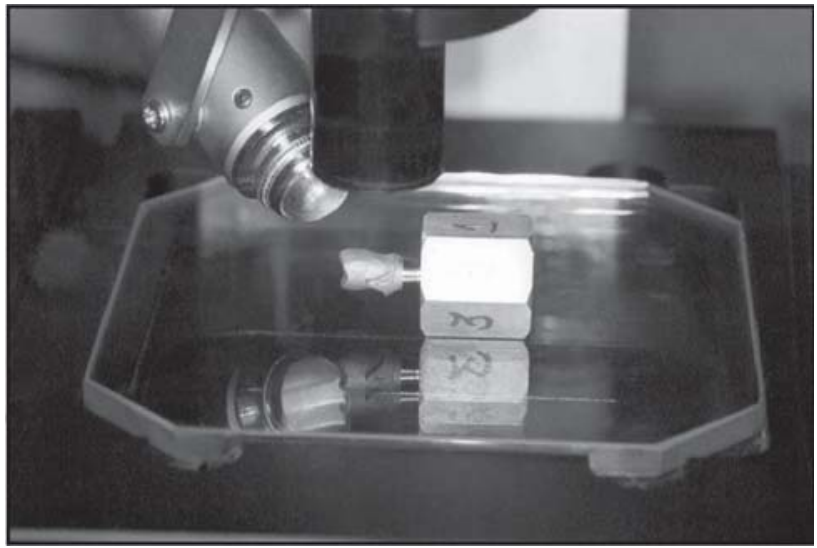

FIGURE 2- Marginal measurement at abutment-cylinder interface

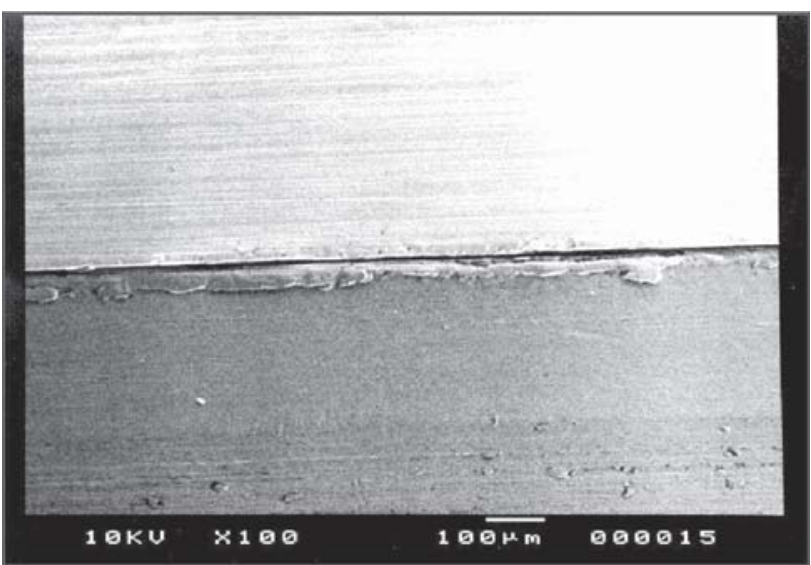

FIGURE 4A- Scanning electron microscope, gold cylinder after casting (10 and $20 \mathrm{Ncm}$ torque values) were analyzed by the Paired $t$ Test $(\mathrm{p}<0.05)$.

\section{RESULTS}

Mean and standard deviations for each group are shown in Table 2. Intragroup differences were observed for G-I (gold, 20Ncm, titanium screw, p=0.044) and for G-II (Ni-Cr$\mathrm{Be}, 10 \mathrm{Ncm}$, gold screw, $\mathrm{p}=0.002$ ). Intergroup differences only were not observed in the G-II group (Ni-Cr-Be, 10 and 20Ncm, titanium screw, $\mathrm{p}=0.534$ ). For the Gold cylinders, marginal fit levels before casting ranged from 12 to $17 \mu \mathrm{m}$, and from 10 to $15 \mu \mathrm{m}$ for the Ni-Cr-Be cylinders. After casting, marginal fit values of Ni-Cr-Be cylinders were higher (15 to $21 \mu \mathrm{m}$ ) than gold ones (9 to $11 \mu \mathrm{m}$ ).

\section{DISCUSSION}

The instability of the prosthetic screw in implantsupported fixed restorations is currently a matter of concern. High failure rates have been reported in several clinical follow-up investigations $s^{1,2,4,5,6,7}$. At the area of premolars and
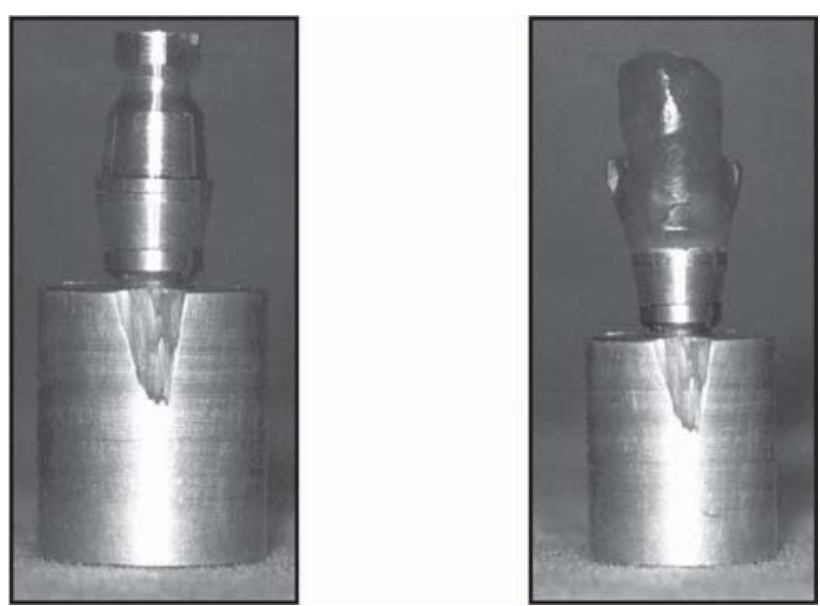

FIGURE 3- Premachined cylinder secured to the implant (left). Wax-up for definitive prosthesis (right)

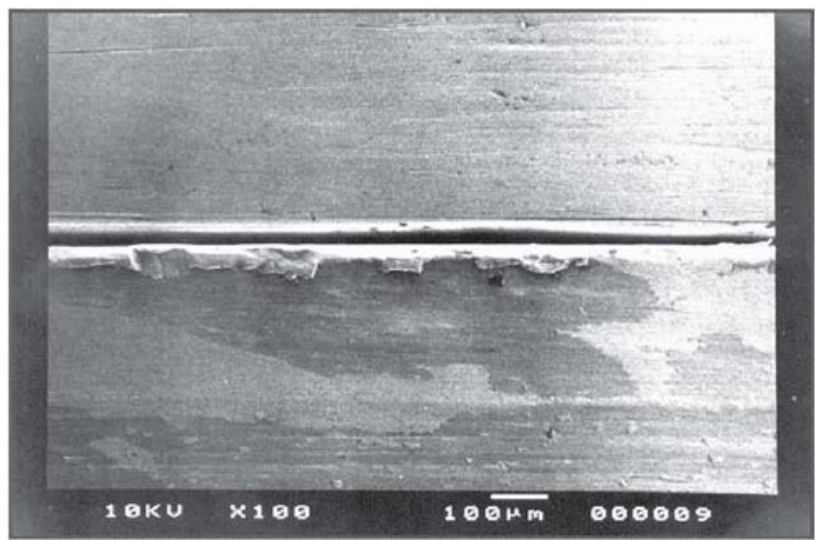

FIGURE 4B- Scanning electron microscope, Ni-Cr-Be premachined cylinder 
molars, high occlusal forces yield an increase in stress on the components and bone tissue, jeopardizing the joint to failure. Even implant-supported single replacements may suffer the deleterious effects of the lack of passivity, due to their complex biomechanical behavior. The clinical performance of these restorations led investigators to suggest utilization of large diameter implants or systems that allow higher stability and consequently higher success rates $^{3,8,9,10}$.

Precision of fit between components is another important factor for stability between implant, abutment and gold cylinder ${ }^{11,12,13,16,17}$. Morphological variations during fabrication of components lead to clinical implications of varying magnitudes. The diameter of the seating base should present minimum morphological variations when compared to the diameter of the abutment and gold cylinder, since differences between them result in the formation of spaces or gaps, plaque accumulation, and adverse tissue response $^{12,13}$.

This study evaluated the vertical fit between Estheticonelike abutments and cylinders with overcasting. Similar to other studies ${ }^{11,13,18}$, acceptable variations were observed in both systems. SEM analysis showed irregularities on the marginal contour of the cylinder/abutment interfaces, which were rounded or beveled at their external portions (Figures 4a and 4b). Similar marginal morphology patterns in both groups prevented a true qualitative analysis. This in part is expected due to the flat nature of the joint, use of premachined components, and the mechanism of fixation (screwed rather than cemented). Besides, no single isolated contact points along the interfaces were observed, which confirms the high quality level of cylinders before overcasting. Unfortunately, attempts to correlate fit values and marginal quality remained unclear in the literature. Although gold cylinders had better fit than Ni-Cr-Be ones, even the smallest gap is at risk for pit corrosion. Besides, clinical follow-up studies do not evaluate external margins qualitatively by means of SEM images obtained from impression-replica or similar techniques. In this way, the use of radiographic analysis to evaluate passive fit seems more practical.

Visual aspect provided by Figures 4a and 4b could lead the less experience clinician to believe that both surfaces have the same level of finishing and polishing. However, due to their intrinsic properties, gold and $\mathrm{Ni}-\mathrm{Cr}$-Be alloys have different tarnish and corrosion resistance, and little information is available on the corrosion products that form under in vivo conditions ${ }^{19}$. Thus, despite the risk of biological impairment, the presence of this condition does not indicate absence of fit, since reading was performed without considering the bevel generated by the components, which would suggest a false misfit. The values achieved represent the real vertical space at the interface. Although these alterations may not influence stability of the joint, they still are relevant from a biological aspect; without proper hygiene measures, plaque accumulation occurs in this area. Of course, polishing level at interface could not account as the only determinant of it.

Ag-Pd and Ni-Cr-Be alloys for overcasting are commonly used in the fabrication of fixed partial dentures (FPDs). Their influence on marginal fit values observed in this study was not so pronounced as in FPDs. Compared to the geometry finishing line of prepared teeth, the more regular cylinderabutment joint provides uniform deposition of wax around the margins. The hypothesis is that the chance for areas with different shrinkage patterns would be less obvious. Nonetheless, differences between G-I and G-II after casting are evident (Table 2). This could be explained by the castability of these alloys. However, both are within an acceptable level of fit $^{11}$. Still, it is not known whether the

TABLE 2- Mean and standard deviation for marginal fit $(\mathrm{mm})$ before and after overcasting procedure

\begin{tabular}{|c|c|c|c|c|}
\hline Cylinder & Screw type & Torque value & Before & After \\
\hline & Gold (n=8) & $10 \mathrm{Ncm}$ & $14.41 \pm 3.84 \mathrm{~A}$ & $11.79 \pm 4.06 \mathrm{~B}$ \\
\hline & & $20 \mathrm{Ncm}$ & $12.26 \pm 3.69 \mathrm{~A}$ & $9.59 \pm 3.25 \mathrm{~B}$ \\
\hline \multicolumn{5}{|l|}{ G-I* (Gold) n=8) } \\
\hline & $\mathrm{Ti}(\mathrm{n}=8)$ & $10 \mathrm{Ncm}$ & $17.26 \pm 5.79 \mathrm{C}$ & $11.59 \pm 4.03 \mathrm{D}$ \\
\hline & & $20 \mathrm{Ncm}$ & $14.99 \pm 5.25$ C,a & $9.41 \pm 3.72 \mathrm{D}, \mathrm{a}$ \\
\hline & Gold $(n=8)$ & $10 \mathrm{Ncm}$ & $14.02 \pm 5.63 \mathrm{E}, \mathrm{b}$ & $20.93 \pm 7.10 \mathrm{~F}, \mathrm{~b}$ \\
\hline \multirow{3}{*}{$\begin{array}{l}\mathrm{G}-I^{* *}(\mathrm{Ni}-\mathrm{Cr}-\mathrm{Be}) \\
(\mathrm{n}=8)\end{array}$} & & $20 \mathrm{Ncm}$ & $10.95 \pm 5.68 \mathrm{E}$ & $15.77 \pm 4.72 \mathrm{~F}$ \\
\hline & $\mathrm{Ti}(\mathrm{n}=8)$ & $10 \mathrm{Ncm}$ & $15.79 \pm 5.87$ & $21.46 \pm 7.27 \mathrm{G}$ \\
\hline & & $20 \mathrm{Ncm}$ & $12.20 \pm 5.19$ & $17.90 \pm 7.06 \mathrm{G}$ \\
\hline
\end{tabular}

Mean values with the same letters indicate statistically significant differences $(p<0.05)$

Capital letters represent intergroup comparisons within the same column.

Small letters represent intragroup comparisons within the same line.

* Overcast with Ag-Pd alloy

** Overcast with $\mathrm{Ni}-\mathrm{Cr}-\mathrm{Be}$ alloy 
simulation of porcelain veneer application (repeated firing cycles) would increase differences on marginal quality of Ni-Cr-Be cylinders. A forthcoming study should address these questions.

Statistically significant differences were observed for the marginal fit values before overcasting in the G-I when gold and titanium screws were employed (Table 2). The same condition is observed in G-I after casting. One interesting aspect is that after casting in G-I, values for marginal fit were almost the same (Table 2, last column). This can be explained because the internal threads of gold cylinder can be deformed in a similar way either with gold or titanium screws. The significant difference at $20 \mathrm{Ncm}$ torque before and after casting in the G-I when the titanium screw was fixed confirms this statement. The alloy for overcasting gold cylinders and the screw type does not influence final results, only the generated torque.

In the G-II group, similar conditions were observed before casting. However, all marginal fit levels were higher than in G-I. This was expected due to the overcasting of alloys with similar compositions. Besides, when the Ni-Cr-Be cylinders are combined with a base metal alloy, gold screws can be effective for reducing marginal fit values only at $20 \mathrm{Ncm}$ torque (Table 2). Gold screws can be elongated more than titanium screws and compensate for the inferior castability of base metal alloys. Thus, a recommended $10 \mathrm{Ncm}$ torque for gold screws does not apply for base metal cylinders. Therefore, an attempt to reduce operational costs with NiCr-Be cylinders can jeopardize the clinical performance of gold screw, since it has to be elongated beyond its mechanical capacity. Although it is known that gold screws cannot withstand repeated $20 \mathrm{Ncm}$ torque values in this situation, even hand-driven mechanisms provide torque values above $10 \mathrm{Ncm}$. Screw fractures possibly may be related to this condition. After casting, statistically significant differences were observed for all subgroups (Table 2, last column). However, for the same applied torque, the gold screw does not achieve similar levels of fit found in the group I. Possibly, there is an incompatibility between the internal threads of Ni-Cr-Be cylinders and the external threads of gold screws. The generated preload is lost because the base metal alloys deform both titanium and gold screw threads. When the same torque values are compared before and after casting in the G-II group, the only significant increase $(7 \mu \mathrm{m})$ occurs at $10 \mathrm{Ncm}$ torque with gold screw, confirming that gold screws cannot be recommended for Ni-Cr-Be cylinders. When the titanium screw is analyzed, a $20 \mathrm{Ncm}$ torque must be applied to reduce marginal misfit. However, titanium screws with $20 \mathrm{Ncm}$ torque cannot be recommended for clinical situations due to the risk of fracture.

Another important aspect is the machining or casting of prosthetic cylinders. Gold alloys and their properties have been indicated for decades and their advantages are well documented in the literature ${ }^{19}$. However, their higher cost favored the diffusion of alternative cobalt-chromium or cobalt-nickel-chromium alloys. The latter presents acceptable characteristics as higher elasticity modulus and resistance, associated to lower density and flexibility ${ }^{19}$.
The use of premachined gold cylinders provides excellent precision of fit, optimizing the physical, mechanical and biological properties ${ }^{8,12,17}$. However, their higher cost impairs utilization in most rehabilitation procedures. This justifies the use of prefabricated Ni-Cr-Be cylinders, with reduced cost and acceptable marginal fit. Within the limits of this study, alternative alloys may be successfully used in singletooth implant restorations, with no damage to the fit between abutment and prosthetic cylinder. However, titanium screws with a $20 \mathrm{Ncm}$ torque are not recommended due to risk of fracture and prosthesis failure.

\section{CONCLUSIONS}

1. Regardless of screw type, marginal misfit was higher for Ni-Cr-Be cylinders after overcasting, but within acceptable levels of fit;

2. The combination gold cylinder with gold or titanium screw was the most effective to reduce marginal misfit;

3. Both screw types did not improve marginal fit of $\mathrm{Ni}-$ Cr-Be cylinders after overcasting;

4. Although a $20 \mathrm{Ncm}$ torque improves marginal fit in all situations, its use is not recommended due to the increased risk of prosthesis failure.

\section{REFERENCES}

1- Jemt T, Lekholm U, Grondahl KA. A 3 year follow-up study of early single implant restorations ad modum Branemark. Int J Period Rest Dent. 1990;10:340-9.

2- Jemt T, Laney WR, Harris D, Henry PJ, Krogh PH Jr, Polizzi G, et al. Osseointegrated implant for single tooth replacement: A 1-year report from a multicenter prospective study. Int J Oral Maxillofac Implants. 1991;6:29-36.

3- Laney WR, Jemt T, Harris D, Henry PJ, Krogh PH Jr, Polizzi G, et al. Osseointegrated implants for single tooth replacement: Progress report from a multicenter prospective study after 3 years. Int J Oral Maxillofac Implants. 1994;9:49-54.

4- Ekfeldt A, Carlsson G, Borjesson, G. Clinical evaluation of singletooth restorations supported by osseointegrated implants: A retrospective study. Int J Oral Maxillofac Implants. 1994;9:179-83.

5- Becker W, Becker C. Replacement of maxillary and mandibular molars with single endosseous implant restorations: A retrospective study. J Prosthet Dent. 1995;74:51-5.

6- Arber L, Zarb G. Clinical effectiveness of implant supported single tooth replacement: The Toronto Study. Int J Oral Maxillofac Implants. 1996;11:311-21.

7- Haas R, Mensdorff-Pouilly N, Mailath G, Watzek G. Branemark single tooth implants: A preliminary report of 76 implants. J Prosthet Dent. 1995;73:274-9.

8- Balshi T, Ekfeldt A, Stenberg T, Vrielinck L. Three-year evaluation of Branemark implants connected to angulated abutments. Int J Oral Maxillofac Implants. 1997;12:52-8. 
9- Levine RA, Clem DS 3rd, Wilson TG Jr, Higginbottom F, Solnit G. Multicenter retrospective analysis of the solid-screw ITI implant for posterior single-tooth replacements: results of loading for 2 or more years. Int J Oral Maxillofac Implants. 1999;14:516-20.

10- Gibbard L, Zarb G. A 5 year prospective study of implant-supported single-tooth replacements. J Can Dent Assoc. 2002;68:110-6.

11- Binon, PP. The External Hexagonal Interface and Screw-Joint Stability: A primer on Threaded Fasteners in Implant Dentistry. QDT. 2000;23:91-105.

12- Guichet DL, Caputo AA, Choi H, Sorensen JA. Passivity of fit and marginal opening in screw and cement retained implant fixed partial denture designs. Int J Oral Maxillofac Implants. 2000;15:23946.

13- Byrne D, Houston F, Cleary R, Claffey N. The fit of cast and premachined implant abutments. J Prosthet Dent. 1998;80:184-92.

14- Brodeck U. The ZiReal Posterior: A new ceramic implant abutment. J Esthet Restor Dent. 2003;15:10-23.

15- Glauser R, Sailer I, Wohlwend A, Studer S, Schibli M, Scharer P. Experimental zirconia abutments for implant-supported single-tooth restorations in esthetically demanding regions: 4 year results of a prospective clinical study. Int J Prosthodont. 2004;17:285-90.

16- Cheshire PD, Hobkirk JA. An in vitro quantitative analysis of the fit of Nobel Biocare implant superstructures. J Oral Rehabil. 1996;23:782-9.

17- Keith SE, Miller BH, Woody RD, Higginbottom FL. Marginal discrepancy of screw-retained and cemented metal ceramic crowns on implant abutments. Int J Oral Maxillofac Implants. 1999;14:36978

18- Sorensen JA, Avera SP, Tomas C. Comparison of interface fidelity of implant systems [Abstract 2191]. J Dent Res. 1991;70:540.

19- Anusavice KJ. Phillips' Science of dental materials. $10^{\text {th }}$ ed. Philadelphia, W.B. Saunders; 1996.

20- Jaarda M, Razzoog M, Gratton D. Ultimate tensile strength of five interchangeable prosthetic retaining screws. Implant Dent. 1996;5:16-9.

21- Burguete R. Tightening characteristics for screwed joints in osseointegrated dental implants. J Prosthet Dent. 1994;71:592-9.

22- Patterson E, Johns M. Theoretical analysis of the fatigue life of fixture screws in osseointegrated dental implants. Int J Oral Maxillofac Implants 1992;7:26-34. 